Ks. Norbert Widok ${ }^{1}$

\title{
Warunki dobrego postu według wybranych pisarzy greckich IV-VI wieku
}

Post wśród wyznawców Jezusa Chrystusa stał się od pierwszych pokoleń chrześcijaństwa oczywistością, ponieważ praktykowanie tego zalecenia należało do istotnych propozycji w nauczaniu Zbawiciela. Z pewnością był różnie akceptowany przez poszczególnych członków wspólnot kościelnych, jednak bez wątpienia pozostawał przedmiotem troski pasterzy tamtych czasów. Świadczą o tym teksty homilii, mów i traktatów, w których przekonują swoich wiernych do przestrzegania zasad postu².

Niniejsze refleksje badawcze w tym względzie odnoszą się do przekazów autorów mniej popularnych, nienależących do wielkich autorytetów pierwszych wieków chrześcijaństwa, niemniej jednak czyniących swe powinności pasterskie niewątpliwie $\mathrm{z}$ dużą starannością. Należą do nich Asteriusz z Amazji (IV-V wiek) biskup Amazei Pontyńskiej w Kapadocji, Marek Mnich (V wiek) zwany Eremitą pochodzący $\mathrm{z}$ terenów Azji

1 Ks. prof. dr hab. Norbert Widok, kierownik Katedry Teologii Biblijnej, Historii Kościoła i Patrologii na Wydziale Teologicznym Uniwersytetu Opolskiego; e-mail: nwidok@uni.opole.pl; ORCID: 0000-0001-6829-2933.

2 Opis tej praktyki przedstawiono w licznych opracowaniach. Oto niektóre z nich: Th. Pichler, Das Fasten bei Basileios dem Grossen und im antiken Heidentum, Innsbruck 1955; H. Musurillo, The Problem of Ascetical Fasting in the Greek Patristic Writers, „Traditio” 12 (1956) s. 1-64; F. Drączkowski, Rewaloryzacja idei postów w nauczaniu Ojców Kościoła, w: Asceza, odczłowieczenie czy uczłowieczenie, red. W. Słomka, Lublin 1985, s. 125-136; P. Libera, ,, Certamen nostrum ieiunium est”. Dynamiczny wymiar postu wedtug świętego Ambrożego, VoxP 15 (1988) s. 745-758; P. Wygralak, Praktyka postu w klasztorach wizygockiej Hiszpanii w VI-VII wieku. Analiza reguł zakonnych, w: Spiritus Sanctus et Ecclesia. Opuscula Bogdano Częsz septuagenario dedicata, red. P. Wygralak, Opuscula dedicata 10, Poznań 2015, s. 33-43; L. Nieścior, Post w czasach ojców Kościoła, w: Post jako praktyka duchowa. Ojcowie Kościoła o poście, red. L. Nieścior, Kraków 2019, s. 11-52. 
Mniejszej, Pseudo-Jan Chryzostom (V-VI wiek) oraz autor ukrywający się pod imieniem Euzebiusza z Aleksandrii (V-VI wiek) nazywany z tego względu Pseudo-Euzebiuszem. Swą pisarską i nauczycielską aktywność prowadzili we wschodniej części Imperium Romanum od połowy IV do początku VI wieku. Zatem zalecenia dotyczące warunków dobrego postu, co jest celem tego przedłożenia, są umieszczone w tekstach powstałych na przestrzeni prawie trzech wieków i na obszarze od Kapadocji po Egipt.

Skoro celem niniejszych zamierzeń jest opis warunków stanowiących wymogi do podjęcia postu, to oznacza, że ich przedstawienie odnosi się do etapu poprzedzającego właściwy okres poszczenia. Zostaną bowiem pominięte kwestie związane $\mathrm{z}$ istota postu i elementami jemu przeciwnymi, a więc postawą obżarstwa czy też brakiem wstrzemięźliwości w jedzeniu ${ }^{3}$. Przedmiotem analizy zatem jest zaprezentowanie elementów przygotowujących umysł i duszę chrześcijanina do podjęcia wysiłku poszczenia. Na tym etapie można wyróżnić kilka kroków, które składają się na całość wstępnej fazy.

\section{Pierwotna zasadność postnej aktywności}

Pasterze wczesnochrześcijańscy, wśród nich wyżej wymienieni, zanim przystąpili w swych homiliach do bezpośredniego nawoływania wiernych do wprowadzenia $\mathrm{w}$ ich codzienne życie postu, podali najpierw kilka założeń będących rozumowymi argumentami podkreślającymi znaczenie tej ascetycznej praktyki. Do nich przede wszystkim należy czynnik rozstrzygający o sensowności podjęcia postu, a jest nim przynależność do religii. $\mathrm{Na}$ tę kwestię zwrócił uwagę Asteriusz z Amazji ${ }^{4}$, który jednoznacznie

3 Szeroką panoramę przeróżnych okoliczności historycznych, religijnych, a nawet dyscyplinarnych odnoszących się do praktyki postu przedstawiają syntetyzujące opracowania, wśród których można wymienić: H.P. Harrera, Legislación eclesiastica sobre el ayuno y la abstinencia: sintesis historica y comentario, Washington 1935; N. Papadopoulos, About the very early Christian Fasting, „Deltiōn Biblikōn Meletōn” 116 (1987) s. 51-65; A. Scarnera, Il digiuno cristiano dalle origini al IV secolo. Contributo per una rivalutazione teologica, Roma 1990; V.E. Grimm, From Feating to Fasting, the Evolution of a Sin: Attitudes to Food in Antiquity, London - New York 1996; S. Bralewski, Praktykowanie postu w świetle historiografii kościelnej IV-V wieku, VoxP 59 (2013) s. 359-378.

4 Na temat jego życia i działalności nie posiadamy zbyt wiele informacji. Wiadomo, że biskupem został między 380 a 390 rokiem. Zachowało się 16 homilii, które ukazują jego zdolności retoryczne. Ich tematyka nie dotyczy ścisłych zagadnień dogmatycznych i egzegetycznych, a raczej kwestii moralnych i liturgicznych. Badacze jego śmierć 
stwierdza: „Chrześcijanom przystoi codzienna skrupulatność i ascetyczna powściągliwość, skoro są w posiadaniu czystej i prawdziwej religii"s. Według niego zatem jedynie ci mogą podjąć ,ascetyczną powściągliwość”, czyli wysiłek postu, którzy zdecydowali się przyjąć religię chrześcijańską. Biskup nazywa ją ,czystą i prawdziwą religią”, co jest momentem godnym podkreślenia w jego wypowiedzi. Innymi słowy, jedynie osoby religijne, to znaczy związane z religią, mają prawo do podjęcia ascezy, skrupulatności i postnej powściągliwości. To podstawowe założenie Asteriusz następnie wyjaśnia, komentując w ten sposób: „Ci natomiast, którzy podejmują się postu bez religijnych pobudek, podobni są według mnie do ludzi, którzy stawiają dom bez fundamentu lub budują statek bez stępki"6. Biskup Amazji stanowczo zatem zakłada, że z dobrodziejstwa postu mogą korzystać osoby, które kierują się religijnymi pobudkami, ponieważ są zaangażowanymi członkami religii chrześcijańskiej.

Działający po 100 latach, prawdopodobnie również w Azji Mniejszej, Pseudo-Jan Chryzostom ${ }^{7}$ chrześcijańską postawę interpretuje bardziej radykalnie, wskazując na ścisłą zażyłość z Bogiem, co niewątpliwie zakłada głęboką religijność człowieka poszczącego. Jego wyjaśnienia w tej kwestii posiadają następujący tok argumentacji: „Ów ożywczy post łączy z Bogiem. Nie da się bowiem inaczej obcować z Bogiem, jeśli najpierw nie zastosuje się lekarstwa postu. Od wieków stanowi on próbę dla ludzi, bo niewstrzemięźliwość lub wstrzemięźliwość czyni ich przyjaciółmi lub wrogami Boga"8. To wskazanie mówcy zakłada wyższy stopień zaangażowania się chrześcijanina $\mathrm{w}$ praktykowanie postu, ponieważ odnosi się nie tyle do jego duszy, lecz do ścisłej zażyłości z Bogiem. Autor tych słów ponadto uważa, że jedynie post pozwala stale $\mathrm{z}$ Nim obcować, a nawet stać się Jego przyjacielem. Na potwierdzenie tego faktu przytacza długą listę osób Starego i Nowego Testamentu, którzy „przy pomocy postu stali

umieszczają w latach 400-431. Zob. F.W. Bautz, Asterius von Amaseia, w: BiographischBibliographisches Kirchenlexikon, t. 1, Hamm 1975, k. 256-257; J. Quasten, Patrologia, t. 2, Casale 1980, s. 303-304; S.J. Voicu, Asterio di Amasea, w: Dizionario patristico e di antichità cristiane, t. 1, red. A. Di Berardino, Casale Monferrato 1983, k. 420-421.

5 Asterius Amasenus, Homiliae, XIV: In principium ieiuniorum 14.

6 Asterius Amasenus, Homiliae, XIV: In principium ieiuniorum 14.

7 Temu autorowi naukowcy przypisują więcej niż tysiąc różnych tekstów, które zostały podzielone na grupy o zróżnicowanym charakterze teologiczno-literackim. Teksty te obejmują głównie homilie. Zob. S.J. Voicu, Une nomenclature pour les anonymes du corpus pseudo-chrysostomien, „Bysantion” 51 (1981) s. 297-305; S.J. Voicu, Giovanni Crisostomo (pseudo), w: Dizionario patristico e di antichità cristiane, t. 2, red. A. Di Berardino, Casale Monferrato 1983, k. 1558-1559.

8 Pseudo-Joannes Chrysostomus, De ieiunio sermones 1-7, 1. 
się Jego przyjaciółmi"”. Słuchacz wpatrzony w postacie biblijne powinien według mówcy zostać zauroczony ich postawą i w następstwie tego także podjać wysiłek ograniczenia przyjmowania posiłków. Dlatego autor kontynuuje podjęty wątek przyjaźni z Bogiem kolejną zachętą: „Czy widzisz, że przez post Bóg wzywa lud nie tylko na kurację, ale także do przyjaźni ze sobą [...]. Czyż bycie przyjacielem Boga to coś innego niż bycie bliskim Bogu? Stań się więc przyjacielem Boga przez post, stań się bliski Bogu przez post" ${ }^{\prime 10}$. Idea przyjaźni była w starożytności wartością szanowaną, zarówno w czasach filozofów greckich, jak i w epoce chrześcijańskiej ${ }^{11}$. Stąd też mówca, nawiązując do niej, dąży do ukształtowania tej relacji także względem Boga. Drogą prowadzącą do osiągnięcia takiego stanu, czyli zażyłości Bogiem, jest zatem post.

Działający również na przełomie V i VI wieku Pseudo-Euzebiusz z Aleksandrii ${ }^{12}$ natomiast podchodzi do postu mniej radykalnie. Jego zasady dotyczące poszczenia są następujące:

Przede wszystkim w czasie Wielkiego Postu wszyscy powinni pościć każdego dnia tak samo z wyjątkiem soboty i niedzieli. Jeśli jednak ktoś jest chory, powinien mieć często dyspensę; każdy chrześcijanin ma obowiązek pościć w czasie Wielkiego Postu, powinni pościć zarówno mnisi, jak i świeccy ${ }^{13}$.

U autora tych słów nie ma odniesienia do Boga, wskazuje on natomiast na obowiązek postu przez każdego chrześcijanina, za wyjątkiem chorego. Dla mówcy zatem kryterium podjęcia postu jest tytuł chrześcijanina. Z tego wynika, że gdy ktoś nie jest chrześcijaninem, nie musi spełniać wymogu poszczenia w Wielkim Poście, ponieważ w jego życiu tego typu okres liturgiczny nie istnieje. Ponadto należy zauważyć, że autor ma na uwadze

9 Pseudo-Joannes Chrysostomus, De ieiunio sermones 1-7, 1.

10 Pseudo-Joannes Chrysostomus, De ieiunio sermones 1-7, 1.

11 Oto niektóre odniesienia do opracowań tego zagadnienia: L. Małunowiczówna, Problem przyjaźni u Bazylego, Grzegorza Teologa i Jana Chryzostoma, RH 16/3 (1968) s. 107-132; C. White, Christian friendship in the fourth century, Cambridge 1992; L. Pizzolato, L'idea di amicizia antico, classico e cristiano, Torino 1993.

12 Wprawdzie ten autor nosi przydomek ,z Aleksandrii”, jednak badacze jego spuścizny zaprzeczają, by pochodził z tego miasta, ponieważ nikt o takim imieniu nie zasiadał na stolicy aleksandryjskiej do XI wieku. Wskazuje się raczej na jego syropalestyńskie pochodzenie ze względu na podobną specyfikę jego egzegezy. Kolekcja 21 lub 22 homilii jemu przypisywanych zawiera różne ich kategorie: liturgiczne, polemiczne przeciw poganom i ascetyczne. Zob. S.J. Voicu, Eusebio di Alessandria (pseudo), w: Dizionario patristico e di antichità cristiane, t. 1, red. A. Di Berardino, Casale Monferrato 1983, k. 1284-1285.

13 Pseudo-Eusebius Alexandrinus, Sermo I. De ieiunio 1. 
mnichów i świeckich jako tych, na których ciąży obowiązek postu, nie wymienił duchownych, czyli biskupów, prezbiterów i diakonów. Można jedynie domniemywać, że na ich temat wypowiedział się w innej mowie.

Istotnym podejściem $\mathrm{w}$ refleksji nad zasadnością postu jest ponadto dostrzeżenie podwójności ludzkiej natury, a więc połączenia w niej duszy i ciała. Od wskazania na tę jedyną w swoim rodzaju jedność biskup Asteriusz rozpoczął swą mowę:

Człowiekowi przypadło w udziale być takim, jaki jest, a jest istotą złożoną z widzialnego ciała oraz rozumnej i bezcielesnej duszy. Natura i godność tych dwóch wymienionych części nie jest taka sama: ciało zostało stworzone jako narzędzie, poruszające się pod zarządem kierującej nim duszy, a dusza została ustanowiona do przewodzenia i panowania jako lepsza nad gorszym ${ }^{14}$.

Powyższe słowa stanowią początek dłuższej wypowiedzi, w której mówca rozwija refleksję na temat ważności duszy i ciała. Idea podwójnej natury w człowieku była bliska każdemu, niezależnie od wykształcenia. Dlatego wskazanie na tę ideę stanowiło ważny element ówczesnego przekazu kaznodziejskiego nakierowanego na osiągnięcie sukcesu - w tej sytuacji zachęcenie jak największej rzeszy chrześcijan do praktykowania postu. Mówca w dosyć jasnych i prostych stwierdzeniach wyjaśnił rolę, jaką mają pełnić w życiu człowieka dusza i ciało. Cała wypowiedź biskupa ma charakter filozoficznego zamyślenia nad fenomenem człowieka jako istoty złożonej.

W odniesieniu do decyzji o podjęciu postu ze względu na duszę i ciało Asteriusz w dalszej części swej mowy przekonuje słuchaczy zaskakującymi stwierdzeniami: „Wyświadcz przysługę duszy, a nie ciągle tylko ciału. Ograniczenie jedzenia karmi duszę, obżarstwo karmi ciało"15. Mówca dostrzega więc ścisły związek ilości przyjmowanego pokarmu względem duszy i ciała: mniej jedzenia karmi duszę, więcej jedzenia natomiast, zwanego przez autora obżarstwem, karmi ciało. Uważa on, że „powstrzymywanie się od pokarmów wyświadcza dobrodziejstwo duszy, która ożywia ciało, natomiast spożywanie jedzenia jest konieczne dla ziemskiego narzędzia" ${ }^{\text {. }}$. Autor nie proponuje całkowitego postu, a jedynie ograniczenie w przyjmowaniu pokarmu, gdyż - jak dopowiada - ,spożywanie jedzenia jest konieczne", aby ciało jako narzędzie duszy mogło funkcjonować. Mniejsza ilość zjadanego pokarmu jest bowiem dobrodziejstwem dla duszy. Dla Asteriusza stanowi ona większą wartość, gdyż

\footnotetext{
4 Asterius Amasenus, Homiliae, XIV: In principium ieiuniorum 1.

15 Asterius Amasenus, Homiliae, XIV: In principium ieiuniorum 9.

16 Asterius Amasenus, Homiliae, XIV: In principium ieiuniorum 9.
} 
,jest święta i bezcielesna, nieśmiertelna i niezniszczalna, jest pokrewna nie ziemi i sprawom tego świata, ale Bogu" "17. Powiązanie jej z boską rzeczywistością stało się dla mówcy argumentem zasadniczym dla podjęcia postu. Mówca, zachęcając słuchaczy do ograniczenia w przyjmowaniu pokarmu, ma zatem na uwadze całego człowieka, to znaczy, że stymulowanie ciała postem wpływa na poprawę jakości duszy, co tym samym przybliża do Boga.

W następnym wieku na duszę i ciało uwagę zwrócił także PseudoEuzebiusz z Aleksandrii. Jego sposób argumentowania jest oparty o pouczenia św. Pawła:

Naucz pościć całe swoje ciało, duszę i ducha, aby wszystkie trzy były zgromadzone w imię Pana, wtedy bowiem Pan jest $\mathrm{z}$ nimi [...]. $\mathrm{Z}$ tego też powodu błogosławiony Paweł modlił się, by nienaruszony duch wasz, dusza i ciało bez zarzutu zachowały się na przyjście Pana naszego Jezusa Chrystusa $(1$ Tes 5,23$)$. Jeśli w ten sposób pościsz całym ciałem, spodziewaj się zbawienia ${ }^{18}$.

Autor przejął trychotomiczne ujęcie człowieka zaproponowane przez filozofię przedchrześcijańską ${ }^{19}$, zastosowane potem przez św. Pawła ${ }^{20}$, aby w ten sposób głębiej i szerzej ukazać istotę postu. Autor wyraźnie stwierdza, że trzy sfery człowieka są ,zgromadzone w imię Pana”, a zatem człowiek, który podjął się postu, dotyka nim całe swoje jestestwo, czyli ciało, duszę i ducha. Jest to zatem ujęcie holistyczne, gdyż cały człowiek ma być przygotowany na przyjście Jezusa Chrystusa, czyli na ostateczne zbawienie. Według Pseudo-Euzebiusza aktywność odnosząca się do postu w danej chwili życia człowieka jest jednocześnie zakotwiczona w czasach eschatycznych.

17 Asterius Amasenus, Homiliae, XIV: In principium ieiuniorum 9.

18 Pseudo-Eusebius Alexandrinus, Sermo I. De ieiunio 5.

19 Na ten temat zob. H. Pfeil, Das platonische Menschenbild, Aschaffenburg 1963; L. Gernet, Anthropologie de la Grèce antique, Paris 1968; M.A. Krąpiec, Ja-człowiek. Zarys antropologii filozoficznej, Lublin 1979, s. 9-13.

20 Zob. niektóre z opracowań tego zagadnienia: W. Prokulski, Hellenizm św. Pawta, RBL 6 (1953) s. 25-50; W.D. Stacey, The Pauline View of Man, London 1956; H. Langerbeck, Paulus und das Griechentum, Göttingen 1968; J.L. Espinel, San Pablo y el Helenismo, „La ciencia tomista” 56 (1979) s. 503-539; R.S. Zdziarstek, Chrystianologia św. Pawła, t. 1, Kraków 1989, s. 57-63. 


\section{Duchowe nastawienie wobec postu}

Podjęcie postu wymaga duchowego przygotowania, czyli etapu wstępnego przed właściwym okresem postu jako czasem wstrzemięźliwości. Starożytni znawcy znaczenia postu w życiu człowieka wskazują na kilka duchowych postaw, które najpierw należy w sobie uformować, aby w sposób należyty podjąc się trudu postnego wyrzeczenia.

Już na początku swej mowy o poście Asteriusz zachęca swych wiernych do radosnego zaakceptowania postu, mówiąc do nich: „przyjmijcie z radością czterdziestodniowy post jako mądrego nauczyciela i matkę cnót"21. Swą krótko brzmiącą zachętę od razu motywuje wskazaniem na podmiotową rangę postu, który jest „mądrym nauczycielem i matką cnót”. Biskup w swej zachęcie kierował się najwyższymi duchowymi wartościami, takimi jak mądrość i cnotliwość. Należą one bowiem w aretologii wczesnochrześcijańskiej do sprawności duchowych wysoko ustawionych ${ }^{22}$. Do tej wstępnie uczynionej uwagi o radosnym przyjęciu postu Asteriusz w dalszej części swej mowy dodaje komentarz wyjaśniający istotę owej radości:

Dlatego niech każdy pobożny człowiek, który kocha Boga bardziej niż przyjemności, z radością i ochotą wejdzie $\mathrm{w}$ ten czas wstrzemię́liwości. Jeśli ktoś jest posępny na początku swej walki, nie jest prawdziwym atletą. Nie bądź ponury jak chłopak wleczony na lekcję, nie szemraj przeciwko tym dniom czystości, nie wyglądaj końca tygodnia jak przyjścia wiosny po ciężkiej zimie, [...], nie smuć się, gdy dom od świtu nie wypełnia się dymem ani kucharz nie stoi przy ogniu ${ }^{23}$.

Przytoczony passus uzasadnia istotę radosnego przyjęcia postu. Autor różnymi obrazami wziętymi z codzienności pobudza wyobraźnię słuchacza, aby był on w stanie zrozumieć postawę duchowej radości jako stanu umożliwiającego wprowadzenie postu najpierw do świadomości, a potem w codzienną praktykę. W procesie przekonywania odbiorców do przyjęcia takiej postawy mówca zdecydował się na potępienie zachowań przeciwnych radości. Dosyć stanowczo zwraca się do nich, mówiąc: „, nie bądź ponury”, ,nie szemraj”, ,nie smuć się", czyli wskazuje na te elementy duchowej natury człowieka, które tworzą przeciwstawne zachowania względem pozytywnego jego usposobienia polegającego także na radości. Podjęcie

21 Asterius Amasenus, Homiliae, XIV: In principium ieiuniorum 2.

22 Przekrojowe omówienie mądrości przedstawiono w: A. Barucq - P. Grelot, Mądrość, w: Słownik teologii biblijnej, red. X. Leon-Dufour, tł. K. Romaniuk, Poznań Warszawa 1982, s. 459-465.

23 Asterius Amasenus, Homiliae, XIV: In principium ieiuniorum 8. 
trudu postnej wstrzemięźliwości biskup porównuje do walki zapaśniczej, a więc do obrazu dobrze znanemu ówczesnemu społeczeństwu, i zakłada, że nie należy być posępnym, gdyż taka postawa uwłacza prawdziwemu zawodnikowi. W tej sytuacji jest nim chrześcijanin akceptujący zasady postu. Pośród nich biskup wymienił tę najważniejszą, a jest nią motywacja religijna: post bowiem podejmuje „każdy pobożny człowiek, który kocha Boga bardziej niż przyjemności”.

Tę samą linię motywacyjną obrał w swoim traktacie ascetycznym Marek Eremita ${ }^{24}$ działający w V wieku. Jego argumentacja jest na wskroś pozytywna, to znaczy uwzględnia religijny charakter podjętego postu. Słowa jego zachęty brzmią następująco:

Jeśli i my chcemy widzieć Boga, wzgardźmy sobą i stańmy się pokorni, abyśmy nie tylko oglądali Go z naprzeciwka, ale także radowali się Nim, gdy w nas mieszka i odpoczywa. W ten sposób nasza głupota stanie się mądra w Jego mądrości, a nasza słabość zostanie wzmocniona w Jego mocy ${ }^{25}$.

Dla Marka Eremity celem życia ascetycznego jest osiągnięcie radości w Bogu i z Bogiem. Warunkiem do osiągnięcia tego stanu jest jednak skupienie uwagi na sobie samym, co polega na przyjęciu postawy pokory, a nawet wzgardy. Są to cechy duchowe, które z kolei są owocem podjętego postu. Pojawia się zatem w jego rozumowaniu łańcuch bezpośrednio zależnych od siebie etapów: najpierw decyzja dotycząca postu, który prowadzi do pokory i wzgardy, czego następstwem staje się zamieszkanie Boga w człowieku i radowanie się Nim. Tak ułożona kolejność zadań ascetycznych należy do inicjatywy człowieka, prowadząc go w ten sposób do Boga. Gdy człowiek osiągnie radość z przebywania z Bogiem, wówczas On przejmuje inicjatywę, wzmacniając ludzką słabość w swej mocy, a zwłaszcza przemieniając ludzką głupotę, jak się wyraził asceta, w Jego mądrość.

W podobny sposób także Pseudo-Jan Chryzostom zachęca do radosnego przeżywania postu. Jego zachęta jest jasno sformułowana: „Oto Jerozolima, oto Chrystus, oto Wielki Post, duchowa kąpiel. Wejdź ochoczo, rozkoszuj się z radością jej wodami, obmyj ciało, obmyj serce, opłucz duszę, oczyść umysł z brudu grzechu wewnątrz i na zewnątrz"26.

24 Niektórzy uczeni uważają, że działał w Egipcie, inni natomiast łączą jego działalność z Azją Mniejszą. Jego pisma zawierają tematykę teologiczną oraz ascetyczną, wśród nich znajduje się traktat $O$ poście. Więcej na jego temat, zob. K. Żółtaszek, Wstęp, w: Marek Mnich, O poście, VoxP 67 (2017) s. 813-818.

25 Marcus Eremita, De ieiunio 4.

26 Pseudo-Joannes Chrysostomus, De ieiunio sermones 1-7, 1. 
Wydźwięk tej zachęty ma charakter wyraźnie chrzcielny, gdyż jej autor odwołuje się do aktów związanych z liturgią chrzcielną. Przytacza bowiem moment duchowej kąpieli połączonej z wejściem do wody i obmyciem ciała. Te korzyści duchowe, które daje chrzest, powinien według Pseudo-Jana Chryzostoma wprowadzić w życie chrześcijanina także post, a są nimi obmycie serca, opłukanie duszy i oczyszczenie umysłu. W czasie chrztu mają miejsce zewnętrzne czynności, które oczyszczają z brudu grzechu. Podobnie post, który jest również zewnętrzną czynnością, a więc powstrzymaniem się od nadmiaru jedzenia, ma doprowadzić do tych samych wewnętrznych, tj. duchowych korzyści. Przytoczenie tego porównania posiada jeszcze głębsze znaczenie, ponieważ autor przenosi słuchacza do Jerozolimy, czyli nad Jordan, gdzie Chrystus przyjmuje chrzest i w ten sposób dowartościowuje ów Wielki Post. Z tych względów słuchacz powinien z radością doznawać rozkoszy w wodach duchowej kąpieli.

W kolejnej mowie Pseudo-Jan Chryzostom dopowiada w tym samym tonie: „W czasie postu bądź radosny, a nie posępny jak hipokryci, którzy wystawiają się na widok innych, tracąc przez to nagrodę za post"27. Autor tych słów poucza, aby czynności związane z poszczeniem dokonywały się w ukryciu, to znaczy bez wystawiania się publicznie. W taki sposób można jeszcze bardziej podkreślić intymny charakter postu, który - jak już wyżej zaznaczył Pseudo-Jan Chryzostom - dotyczy duchowych korzyści. W obecności innych natomiast, czyli w sytuacji zewnętrznych działań, należy zachować postawę radości, która powinna być skutkiem podjętego wysiłku, a jednocześnie nagrodą za post. To zalecenie w swej treści bliskie jest nauczaniu Jezusa Chrystusa, który opisuje człowieka poszczącego (Mt 6,1-6.16-18) ${ }^{28}$.

Postawię radości i odrzucenia przygnębienia zaleca także PseudoEuzebiusz z Aleksandrii, który działał na przełomie V i VI wieku. W początkowych passusach swej mowy autor najpierw gani tych, którzy przyjmują postawę przeciwną radości, i dosyć stanowczo zwraca się do słuchacza, mówiąc: „,Dlaczego jesteś przygnębiony, gdy pościsz? [...] Dlaczego się smucisz?"'29. Te pytania mają wyzwolić u niego chwilę refleksji wobec praktyki postu, po czym sam autor podaje kilka zachowań negatywnych po to, aby mógł się ich wystrzegać. Słowa mówcy demaskują wszelkie przejawy hipokryzji, gdy stwierdza: „Wielu pości we włosienicy, popiele i we łzach, przybiera posępny wygląd, czuje wstręt do kobiet, gani postawę radosnych, zwraca uwagę, by widać było, że poszczą, i chce uchodzić za pobożnych: taki post nie jest miły Bogu" ${ }^{\prime 30}$. Wymienione przez mówcę ne-

27 Pseudo-Joannes Chrysostomus, De ieiunio sermones 1-7, 2.

28 W obecnym kalendarzu liturgicznym ta perykopa jest czytana w Środę Popielcową.

29 Pseudo-Eusebius Alexandrinus, Sermo I. De ieiunio 3.

30 Pseudo-Eusebius Alexandrinus, Sermo I. De ieiunio 6. 
gatywne postawy względem radosnego przeżywania postu stają się pomocną wskazówką dla każdego, kto ma zamiar wejść na drogę postu lub kroczy już tą drogą. Podane zachowania, wprawdzie uchodzą za niezmiernie ascetyczne, to według mówcy nie mogą być okazją do zwrócenia uwagi innych, gdyż wówczas są to jedynie pozory postu. Dlatego tego typu postawa nie może być akceptowana przez Boga.

Po negatywnym podejściu do postu Pseudo-Euzebiusz przechodzi do pozytywnej zachęty i dodaje:

Pość natomiast, jak powiedział Pan, z radością i weselem, i ze szczerą miłością do wszystkich ludzi. A gdy to wszystko wypełnisz, gdy posiądziesz dobrą cnotę i wszelką sprawiedliwość, nie wpadaj w pychę z powodu swoich dobrych uczynków ani nie uważaj się za kogoś wielkiego ${ }^{31}$.

Te słowa zostały wypowiedziane pod koniec mowy, aby w umysłach słuchaczy pozostał pozytywny odbiór przekazanych im pouczeń o istocie postu, a przede wszystkim czynnościach przygotowawczych, zanim nastąpi okres Wielkiego Postu. Należy bowiem napełnić się optymizmem, który rodzi radość, wesele i miłość do wszystkich, i tymi postawami promieniować podczas wysiłku poszczenia. Owocem końcowym tak podjętego zadania będzie, w opinii mówcy, dobra cnota i wszelka sprawiedliwość. Autor nie podaje szczegółowych osiągnięć, gdy minie czas postu, a jedynie wskazuje na pozytywny skutek zdobycia duchowych korzyści. Przy tym przestrzega tych, którym uda się zdobyć dobrą cnotę i wszelką sprawiedliwość, aby nie wpadać w pychę. Jak można zauważyć, układ poszczególnych zaleceń i sposób wartościowania kolejnych wskazań i pouczeń świadczy o znawstwie przez Pseudo-Euzebiusza ludzkiej psychiki i toku duchowej formacji.

Obok wezwania do radosnego przeżywania okresu Wielkiego Postu wymienieni autorzy chrześcijańscy zachęcają ponadto do pozyskania innych cech osobowościowych, aby czas postu przeżyć pozytywnie. Asteriusz z Amazji w sposób zdecydowany zwraca się do słuchacza:

Nie oskarżaj fałszywie Wielkiego Postu, że powoduje choroby, bo wręcz przeciwnie - przynosi zdrowie. Nie szukaj wymówek, by grzeszyć z ludźmi, którzy sobie dogadzają. Wstrzemięźliwość sprawia ci trudność, bo przywykłeś do zła, nie dlatego że jest z natury uciążliwa ${ }^{32}$.

Mówca nie odnosi się do kryteriów biblijnych lub przykazań kościelnych, ale przywołuje codzienność słuchacza, która naznaczona jest raczej

31 Pseudo-Eusebius Alexandrinus, Sermo I. De ieiunio 8.

32 Asterius Amasenus, Homiliae, XIV: In principium ieiuniorum 11. 
negatywnymi zachowaniami. Autor jako negatywne podejście do postu wymienił dogadzanie przechodzące $\mathrm{w}$ grzeszne czynności, przywiązanie do zła, szukanie wymówek, a nawet oskarżanie Wielkiego Postu powodującego choroby. Te rzekome zarzuty słuchacza zostały w dalszej części mowy zdecydowanie przez autora obalone. Po nich delikatnie poddaje refleksji myśli skłaniające go do wyboru: ,jeśli będziesz żył i przyjaźnił się z przyjemnościami i hulankami, nigdy nie pokochasz postu, [...], unikajmy uwikłania $\mathrm{w}$ przyjemności jak tylko jesteśmy w stanie, bo nie można być jednocześnie miłośnikiem przyjemności i Boga"33. Mówca zatem pragnie oderwać ówczesnych chrześcijan od swawolnego życia, które charakteryzowało się hulankami, a im bez wątpienia towarzyszyły biesiadne uczty niemające nic wspólnego ze wstrzemięźliwością w jedzeniu.

Do nabycia postaw umożliwiających podjęcie decyzji o poście namawia także Pseudo-Jan Chryzostom, mówiąc: ,znienawidźmy chciwość, ćwiczmy cnoty, unikajmy zła, pożądajmy dobra, strzeżmy się przyjemności, ukochajmy czystość, wyrzeknijmy się podstępu, odnośmy się do siebie nawzajem z prostotą" ${ }^{34}$. Okazuje się, że lista pozytywnych cech potrzebnych do przyjęcia przed praktykowaniem postu jest o wiele dłuższa. Te słowa pojawiają się w zakończeniu mowy i stanowią swego rodzaju jej podsumowanie, a więc tworzą zachętę kierowaną do słuchacza, aby już przed postem kierować się w życiu wymienionymi cnotami. Należy jednak przyjąć, że nie sposób nabyć wszystkich tych cnót jednocześnie, ale raczej tworzą one listę propozycji do wyboru.

W innej mowie Pseudo-Jan Chryzostom przenosi akcent na wygląd duszy u słuchaczy, do których zwraca się: „Znowu czas postu, [...] znowu głosi się coroczne przyjście Chrystusa. Oczyśćmy się wszyscy, aby Go przyjąć”, a nieco dalej: „Przygotuj duchową świątynię, ozdób ją cno-

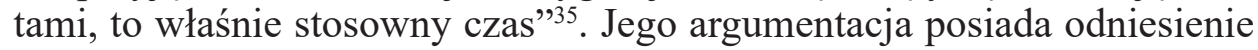
do Chrystusa, czyli On jest powodem, dla którego należy podjąć wysiłek postu. Przyjście Chrystusa powinno mieć uroczysty charakter, dlatego duchowa świątynia chrześcijanina także powinna mieć odświętny wygląd. Według mówcy oznacza to ozdobienie jej cnotami, co wymaga wielu konkretnych zabiegów, do których Pseudo-Jan Chryzostom zaliczył następujące: „Wyrwijmy przyjemności, zasadźmy wstrzemięźliwość, wyburzmy zło, odbudujmy cnoty; wykorzeńmy kłamstwo, zbierzmy owoce prawdy; wypleńmy pychę, przyjmijmy pokutę, wytnijmy gniew, zasiejmy łagodność ${ }^{36}$. Należy przyznać, że oczyszczenie duchowej świątyni, czyli duszy

\footnotetext{
33 Asterius Amasenus, Homiliae, XIV: In principium ieiuniorum 12.

34 Pseudo-Joannes Chrysostomus, De ieiunio sermones 1-7, 3.

35 Pseudo-Joannes Chrysostomus, De ieiunio sermones 1-7, 3.

36 Pseudo-Joannes Chrysostomus, De ieiunio sermones 1-7, 3.
} 
chrześcijanina, wymaga wielu zabiegów: jedne są wyeliminowaniem negatywnych postaw, drugie natomiast polegają na wprowadzeniu pozytywnych zachowań.

Bardzo istotne wskazanie dla chrześcijan mających podjąć wysiłek poszczenia podał Pseudo-Euzebiusz z Aleksandrii, a dotyczy ono opanowania języka. Jego wezwanie w tej kwestii jest zdecydowane:

Ten, który pości, powinien być wstrzemięźliwy pod każdym względem, a przede wszystkim powinien powściągać język. Nie samo tylko powstrzymywanie się od pokarmów nazywa się postem, ale podczas postu powinieneś wystrzegać się mściwości, popędliwości, gniewu, zazdrości, kłótni, walki, kłamstwa, zawiści, obmowy. [...] Nic nie jest groźniejsze od języka; język jest narzędziem każdego naszego grzechu ${ }^{37}$.

Powyższy cytat jest jedynie wstępną informacją, którą następnie mówca szerzej rozwija, odwołując się do tekstów Pisma Świętego i obrazów zaczerpniętych z codziennego życia, aby pokazać negatywne funkcjonowanie języka. W rozumieniu Pseudo-Euzebiusza post od pokarmów musi być połączony z formacją duchową, która ogarnia - jak podaje jego wypowiedź - dużo przestrzeni sfery wewnętrznej człowieka. Mówca ma na uwadze relację względem drugiej osoby, wobec której poszczący musi wyzbyć się tzw. grzechów mowy, a więc kłótni, walki, kłamstwa i obmowy. Powstają one na gruncie innych negatywnych postaw wobec bliźniego, do których autor zaliczył mściwość, popędliwość, gniew, zazdrość i zawiść. Te pierwsze stanowią zewnętrzne przejawy wadliwej relacji, dostrzegalne nawet przez postronnych obserwatorów. Te drugie natomiast tworzą duchowe wyposażenie człowieka o wadliwej strukturze, niewidoczne bezpośrednio dla innych, a tymczasem z ogromną mocą wymierzone są wobec innych ludzi. Chrześcijanin, zamierzający wejść na droge postu, powinien zatem wcześniej uświadomić sobie ogrom czekających go wysiłków odnoszących się do umiejętności posługiwania się mową, która powinna być wolna od wszelkich złych zamiarów względem bliźniego. Pod koniec swej rozbudowanej argumentacji w tej kwestii dodaje: „Ten, kto pości, powinien przede wszystkim powstrzymać język od paplania, podstępów, potwarzy, wyśmiewania i kpin. Inaczej lepiej, żeby nie pościł, bo drwi z samego siebie"38.

W powyższym wywodzie w kwestii posługiwania się językiem jako formy postu Pseudo-Euzebiusz ma na uwadze relację względem bliźnich.

37 Pseudo-Eusebius Alexandrinus, Sermo I. De ieiunio 4.

38 Pseudo-Eusebius Alexandrinus, Sermo I. De ieiunio 4. 
Nastąpiło zatem u tego autora przesunięcie akcentu: obok osobistych korzyści duchowych poszczący swoimi wysiłkami obejmuje także bliźnich.

$\mathrm{W}$ mowach o poście pojawia się inna ponadto kwestia, mocno podkreślana przez ich autorów, a mianowicie towarzysząca tej praktyce modlitwa. Asteriusz jest bowiem w pełni przekonany, że post nie jest próbą łatwą, o czym tak wzmiankuje: „Post to nie głodowanie, ale niewielka zwłoka, nie niezasłużona kara, ale dobrowolne wyrzekanie się, nie niewolniczy przymus, ale dobrowolna asceza". Bezpośrednio do tych słów dodaje: „Módl się, a będziesz silniejszy, wzywaj Boga, a niezwłocznie ci pomoże"39. Według Asteriusza post sam dla siebie nie jest tak wartościowy jak ten, który jest praktykowany w duchu modlitwy. Jest ona jednocześnie prośbą skierowaną do Boga o wytrwanie w trudach postu, do której mówca zachęca.

Na ten sam aspekt zwraca także uwagę Marek Eremita - obecność modlitwy, która powinna towarzyszyć postowi. Na zasadzie dialogu z potencjalnym rozmówcą daje odpowiedź na pytanie przez niego postawione: „Jeśli sprawiedliwość jest w modlitwie, to jaki jest pożytek z postu?"40. W tym pytaniu tkwi wątpliwość rozmówcy co do postu w przypadku, gdy ktoś żyje sprawiedliwie w oparciu o modlitwę. Tę kwestię Marek Eremita rozwiązuje przywołaniem czynności wykonywanych przez rolnika i odpowiada: ,jak rolnik, jeśliby obsiał jałową ziemię, nie użyźniwszy jej [wcześniej], zamiast pszenicy zbierze ciernie, tak samo my, jeślibyśmy zasiali słowa modlitwy, a nie umartwili naszego ciała postem, zamiast [plonu]

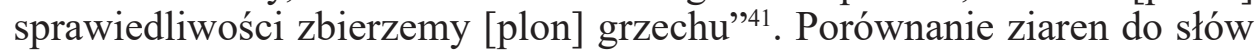
modlitwy jest niewątpliwie obrazem przemawiającym do słuchacza, podobnie jak czynność użyźnienia ziemi zestawiona $\mathrm{z}$ umartwieniem ciała postem. $Z$ tego wynika niezwykle radykalna puenta wypowiedziana przez ascetę: plonem modlitwy pozbawionej postu nie jest sprawiedliwość, ale grzech. Tego typu radykalność pochodzi ze sposobu życia, jakie prowadził Marek Eremita przyzwyczajony do wygórowanych praktyk ascetycznych. W swym traktacie pragnął podzielić się osobistymi doświadczeniami, proponując czytelnikowi te same lub podobne sposoby uprawiania duchowych ćwiczeń.

W nieco innym świetle stawia modlitwę Pseudo-Jan Chryzostom. Jego wypowiedź w tym względzie jest następująca:

Mamy bowiem do pomocy sprzymierzeńca - siostrę postu, czyli modlitwę; choćby groziła nam śmierć, tortury czy jakiekolwiek inne zło, modlitwą i po-

\footnotetext{
39 Asterius Amasenus, Homiliae, XIV: In principium ieiuniorum 12.

40 Marcus Eremita, De ieiunio 3.

41 Marcus Eremita, De ieiunio 3.
} 
stem je pokonamy. [...] Post wypędza demony, obala diabła, szczególnie wtedy, gdy ma do pomocy modlitwę ${ }^{42}$.

Mówca traktuje modlitwę jako ,siostrę”, a więc stawia na równi z postem. W tym kontekście zarówno post, jak i modlitwa pełnią ważną rolę w zwalczaniu wszelkiej formy zła, jak tortury, demony czy działanie szatana. Powyższa wypowiedź bez wątpienia została zainspirowana nauką Chrystusa wyłożoną w kazaniu na górze. Niewątpliwie skoro według Pseudo-Jana Chryzostoma modlitwa jest sprzymierzeńcem, to pełni także rolę wzmacniającą podczas wypełniania postnej praktyki. Przede wszystkim jednak w jego założeniu modlitwa ma ochraniać poszczącego przed atakami demonów i diabła, a także pełnić rolę wspomagającą.

Wątek wzięty z nauki Jezusa Chrystusa Pseudo-Jan Chryzostom w całej rozciągłości przytoczył ponadto w innej mowie, obwieszczając: „Modlitwa i post są dziełem aniołów [...]. Kiedy do modlitwy i postu doda się jałmużnę, wtedy przed Bogiem znajduje się bogaty wykonawca dzieł pobożności”43. Wyszczególnione trzy praktyki ascetyczne wzajemnie się uzupełniają i w ten sposób, co podkreśla mówca, ukazują szerszy horyzont pobożnych praktyk. Zatem dla autora powyższych słów postowi powinna towarzyszyć modlitwa i jałmużna.

\section{3. Świadomość doczesnych skutków postu}

Zanim pojawi się decyzja o podjęciu wstrzemięźliwości, ważną kwestią jest także uświadomienie sobie pozytywnych następstw wynikających z praktykowania postu. Chrześcijanin stojący u progu okresu postu musi także mieć przed oczyma pozytywne następstwa wynikające z podjętej praktyki. Jedne odnoszą się do ciała, inne - do duszy.

W odniesieniu do dobrotliwych następstw względem ciała Asteriusz wymienia szeroki ich wachlarz i z naciskiem podkreśla:

[...] przysługę wyświadcza nam post, gdy gasi zgagę wywołaną obżarstwem [...]. Łagodzi otyłość, zmniejsza ciężar ciała, uwalnia żyły od nadmiaru krwi [...]. Głowa jest w łagodnym i spokojnym stanie, gdy ani arterie nie drgają, ani wznoszące się wyziewy nie zaciemniają mózgu. Wstrzemięźliwość przynosi wolność żołądkowi, bo wyzwala go od przymusowej pracy i gotowania się jak kocioł przy uciążliwym trawieniu. Wzrok jest czysty i niezmącony,

\footnotetext{
42 Pseudo-Joannes Chrysostomus, De ieiunio sermones 1-7, 2.

43 Pseudo-Joannes Chrysostomus, De ieiunio sermones 1-7, 5.
} 
gdy nie ma soków trawiennych, które przy przesycie zwykle zalewają oczy. Nogi się nie plączą, ręce się nie trzęsą. Oddech jest regularny i miarowy, gdy żadne wzdęcie nie uciska wnętrzności [...]. Sen spokojny i bez koszmarów ${ }^{44}$.

Wymienione w tej wypowiedzi somatyczne skutki postu biskup podał na początku swej mowy, by następnie przejść do argumentacji biblijnej polegającej na przywoływaniu tych scen ze Starego Testamentu, w których poszczególne osoby popełniły nieodwracalne błędy z powodu obżarstwa, pijaństwa lub braku wszelkiej wstrzemięźliwości. Odnośnie do takich zachowań podaje także przykłady błędnych decyzji wodzów i plemion żyjących na obszarze ówczesnego świata. Te biblijne i świeckie negatywne przykłady podane przez mówcę miały na celu wywołanie u słuchaczy nieomal wstrząsowej reakcji. Tego typu sposób przemawiania stanowił przyjętą w starożytności formę apotreptyku, czyli zniechęcenia do niektórych zachowań. Jednak punktem wyjścia był przytoczony wyżej spis pozytywnych owoców podjętego postu mających bezpośrednie przełożenie na jakość funkcjonowania organizmu ludzkiego. Należy ponadto pochwalić dietetyczno-medyczne znawstwo Asteriusza. Z pewnością sam osobiście doświadczył tych cielesnych dobrodziejstw, skoro z takim przekonaniem o nich pisze.

O sto lat później żyjący Pseudo-Jan Chryzostom natomiast nieco w skróconej formie także wymienia korzyści dla ciała wynikające z praktykowania postu: ,[...] post zapewnia zdrowie ciału, post zabezpiecza domostwo, jest nauczycielem młodzieży, stróżem dzieci, umiarkowaniem starców, ozdobą i łagodnością kobiet" ${ }^{4}$. W tej wypowiedzi akcent położony został nie tylko na ciało i zdrowie poszczącego, ale także na usposobienie członków jego rodziny. Wartość owoców wynikających z podjęcia przez niego trudu postu autor odnosi do osób z jego najbliższego otoczenia. Niewątpliwie tego typu postrzeganie omawianej problematyki jest propozycją dosyć oryginalną. Skoro mówca ją zaproponował w przemówieniu na rozpoczęcie Wielkiego Postu, to najprawdopodobniej poznał jej dobrotliwe skutki na podstawie wcześniejszych swoich doświadczeń. Należy przyznać, że pozytywny wpływ poszczącej osoby na członków jego rodziny jest wieloraki, jak to pokazuje treść powyższej wypowiedzi.

Całkowicie inne rozpatrzenie postu $\mathrm{w}$ odniesieniu do ciała zaleca Pseudo-Euzebiusz z Aleksandrii. Naucza, że ,,post przynosi dwie korzyści: po pierwsze, osiąga się pomniejszenie ciała; natomiast dla żyjących w małżeństwie nakazano post po to, by podzielili się z biedakami chlebem i winem. [...] Post jest ważny, gdy ty pościsz, a biedny korzysta z twojego

\footnotetext{
44 Asterius Amasenus, Homiliae, XIV: In principium ieiuniorum 2.

45 Pseudo-Joannes Chrysostomus, De ieiunio sermones 1-7, 5.
} 
jedzenia"46. Bez wątpienia pierwsza uwaga związana z postem jest jednoznacznie wyartykułowana i powszechnie przez jej odbiorców pojmowana, gdyż mniejsza ilość zjadanego pokarmu powoduje „pomniejszenie ciała”. Dosyć specyficznie brzmiącą sugestią co do postu natomiast jest drugie zalecenie skierowane jedynie do żyjących w małżeństwie. Ich post powinien być praktykowany z myślą o biednych. Jeśli bowiem biedny otrzymuje jakąś strawę dzięki ograniczaniu jedzenia przez małżonków, to dopiero wówczas ich post jest ważny, spełniając przy tym dobroczynną rolę. Autorowi zależało zatem na ukazaniu relacji pomiędzy ludźmi żyjącymi w małżeństwie w sposób dostatni a biednymi, która to relacja poprzez zaproponowaną przez autora postawę postu uczy miłości bliźniego i poszanowania jego godności.

Lektura omawianych mów wykazuje, że jeszcze większy nacisk położono na skutki postu dla duszy. Różne zalecenia w tym względzie na początku swej mowy wymienił Asteriusz, biskup Amazji, który odniósł się do kilku aspektów sfery duchowej:

Jego surowość i świętość usypia żądze, gasi gniew i wzburzenie, uspokaja i uśmierza dusze spowodowane przejedzeniem [...]. Poszczący mówi wyraźnie i elegancko, umysł ma jasny, i wtedy naprawdę jest podobny do Boga, gdy uskutecznia swoje działanie bez smutku i bez niepokoju jakby w bezcielesnym ciele. Sen spokojny i bez koszmarów. Krótko mówiąc, post przynosi wspólny spokój duszy i ciału, harmonijne życie, porządne prowadzenie się, zachowanie miłe $\mathrm{Bogu}^{47}$.

Ta dłuższa wypowiedź biskupa dotycząca skutków postu dla duszy posiada dwa odniesienia. Pierwsze dotyczy samego poszczącego, gdyż ukazuje pozytywne wpływy na jakość jego duszy realizujące się w konkretnych postawach: działa bowiem uspokajająco na żądze, gniew i wzburzenie. Są to te zachowania ludzkie, które są wymierzone przeciwko bliźniemu i wzajemnemu współżyciu. Tymczasem post wprowadza w codzienność pozytywne nastawienie wobec innych, a więc harmonijne życie, porządne prowadzenie się, a przede wszystkim zachowanie miłe Bogu, jak dodaje biskup. Ta ostatnia $\mathrm{z}$ wymienionych postaw stanowi o drugim odniesieniu, czyli tym względem Boga. Asteriusz podaje kilka zachowań charakteryzujących duszę poszczącego, który mówi wyraźnie i elegancko, umysł ma jasny, działa bez smutku, ma sen spokojny i bez koszmarów. Według biskupa te cechy sprawiają, że poszczący staje się wręcz podobny do Boga, a jego aktywność dokonuje się jakby w bezcielesnym ciele.

\footnotetext{
46 Pseudo-Eusebius Alexandrinus, Sermo I. De ieiunio 2.

47 Asterius Amasenus, Homiliae, XIV: In principium ieiuniorum 2.
} 
Należy zauważyć, że nauczanie Asteriusza o pożytku postu zawiera bardzo ważne założenie, o którym już wyżej wspomniano - obejmuje duszę i ciało, a więc mówca w swych zachętach zakłada jedność psychofizyczną człowieka. Prawie każda wypowiedź biskupa zawiera zalecenia uwzględniające obydwie sfery człowieka. Stąd też w cytowanej wyżej zachęcie zaznaczył, że „,post przynosi wspólny spokój duszy i ciału”.

Wiele interesujących spostrzeżeń w tym względzie podaje Pseudo-Jan Chryzostom. Początek pierwszej mowy o poście stanowi swoisty program zadań do spełnienia. Poszczególne elementy tej programowej zachęty zostały przez niego następnie doglębniej rozpracowane w kolejnych mowach o poście. Jej treść ukazuje radykalność wymagań biskupa wobec swych odbiorców:

Czego post nie leczy? Jakiej namiętności nie usuwa z duszy? Odnawia serce przez wypędzenie sytości nieopanowania; powściąga wybuchy gniewu przez odebranie zbytków życia; zakleja jak plaster zatwardziałość nienawiści; wycina narośle namiętności; zbija gorączkę przyjemności; przekłuwa nadęte fantazje próżnej chwały; przepędza bezsenność spowodowaną zmartwieniami; usuwa ropę zuchwalstwa z kącików oczu; oczyszcza zmysły ciała i duszy; [...]. Kto więc jest miłośnikiem zdrowia, niech dobrowolnie przepisze sobie post ${ }^{48}$.

Autor tych słów umieszcza poszczególne dobrodziejstwa duchowe, które stają się następstwem postu, w kontekście leczenia, czyli przeprowadzania duchowej kuracji. Tą myślą rozpoczyna wyliczanie uzdrawiających zabiegów i także kończy je, wyzwalając u słuchaczy pragnienie posiadania zdrowia „duszy i ciała”, jak zaznacza. To zdrowotne odniesienie stanowi sposób pozyskania odbiorców i jednocześnie zachęcenie do zdecydowania się na podjęcie postu. Lista korzystnych dla duszy osiągnięć jest niezwykle pociągająca, ponieważ człowiek oczyszcza się z dosyć poważnych wad duchowych, wśród których mówca wymienił nieopanowanie, gniew, nienawiść, namiętność, przyjemności, próżną chwałę i zuchwalstwo. Chrześcijanin w sposób poprawny myślący o swojej pobożności, po wysłuchaniu tak brzmiącej zachęty, powinien poddać się autorefleksji i zmierzyć się z trudami postu, aby wymazać te duchowe przywary.

Pseudo-Jan Chryzostom w dalszej części mowy wylicza z kolei zalety, które pojawią się w duszy człowieka, gdy usunie istniejące w niej wady już wyżej przez mówcę podane. Tak uformowany na duchu człowiek wstępuje na wyższy poziom duchowości, gdyż staje się przyjacielem Boga, o czym także już wspomniano. W następnej mowie ponownie przypomina o ko-

48 Pseudo-Joannes Chrysostomus, De ieiunio sermones 1-7, 1. 
rzyściach wynikających dla duszy, stwierdzając, że ,post leczy rany duszy, post wzmacnia duszę osłabioną grzechami, odnawia duszę, napełnia męstwem umysł, wprowadza bojaźń Bożą, niszczy namiętności, uspokaja myśli" ${ }^{\prime \prime}$. Autor w swej wypowiedzi odniósł jedne korzyści postu do duszy, inne natomiast - do umysłu. Te dotyczące duszy uzdrawiają ją z ran doznanych przez grzechy, która będąc przez nie osłabiona, na nowo zdobywa moc duchową. Dla mówcy zatem post w odniesieniu do duszy oznacza przybycie jej na ratunek i wyzwolenie od jarzma grzechu. Te pozostałe korzyści przynoszą wiele dobra dla umysłu, a są pośród nich męstwo, bojaźń Boża, zniszczenie namiętności i uspokojenie myśli. Ten, kto ma zamiar podjąć trud postu, bez wątpienia powinien okazać się przekonany do jego akceptacji po wysłuchaniu tylu powodów przemawiających za słusznością tej ascetycznej praktyki.

Sens praktyki postu Pseudo-Jan Chryzostom odniósł także do postu Jezusa Chrystusa. Czyni to w ostatniej mowie, gdzie w jej zakończeniu jakby na podsumowanie omawianej tematyki wskazuje na wartości wynikające z przykładu Zbawiciela, który pościł przez czterdzieści dni. Słowa mówcy są wyliczeniem duchowych osiągnięć kierowanym do wszystkich członków ówczesnej wspólnoty, a więc do wiernych i siebie samego: ,$[\ldots]$ wykorzeniamy ciernie, znikają przyjemności, niszczeją dzieła diabła, uświęcają się wody Jordanu, odradza się człowiek, zstępuje Duch Święty, dostępujemy życia i zmartwychwstania"50. Wymowa tego tekstu jest nieco głębsza ze względu na wskazanie zasług, jakie wniósł Jezus Chrystus w dzieje zbawienia, a więc także w życie każdego człowieka. Autor uświadamia słuchaczy, że to właśnie Chrystus zniszczył dzieła diabła, uświęcił wody Jordanu i dlatego zstąpił Duch Święty. Pojawił się tu kontekst chrztu Chrystusa na zakończenie okresu Jego postu i wynikające $\mathrm{z}$ tego konsekwencje: odrodzenie człowieka i dostąpienie przez niego życia i zmartwychwstania. Post Chrystusa ma zatem wyraźnie zbawcze zbawienie wprost adresowane do ludzi, którzy dzięki temu przez swoje zaangażowanie mogą wykorzenić ciernie i usunąć przyjemności.

O korzyściach dla duszy płynących z podjęcia postu poucza także Pseudo-Euzebiusz z Aleksandrii. Zwraca się do słuchacza słowami: „Zobacz, jak wielkie zyski przynosi nam post: niezmącony umysł, spokojne myśli, łagodne serce, głowę bez bólu, pewny chód. Kiedy pościsz, twoje członki są spokojne"51. Mówca z Aleksandrii zwraca uwagę na zdobycie korzyści w sferze intelektualnej człowieka, czyli wpływające na jego niezmącone i spokojne myślenie powodujące łagodność serca. Te umysłowe

\footnotetext{
49 Pseudo-Joannes Chrysostomus, De ieiunio sermones 1-7, 2.

50 Pseudo-Joannes Chrysostomus, De ieiunio sermones 1-7, 7.

51 Pseudo-Eusebius Alexandrinus, Sermo I. De ieiunio 3.
} 
zalety Pseudo-Euzebiusz z kolei powiązał z wpływem na fizyczną sferę człowieka, dostrzegając związek między nimi a spokojnym chodzeniem. $\mathrm{O}$ sferze duchowej natomiast wypowiedział się w innym miejscu swej mowy, gdzie m.in. stwierdził, że post „ocala poszczących od złej śmierci, od ognia, zawiści i zazdrości”"52. Położył więc nacisk na groźne wady w relacjach międzyludzkich, tj. zawiści i zazdrości, które spychają na plan dalszy miłość bliźniego będącą zasadniczą zasadą i normą życia chrześcijańskiego. Te wady utożsamia z ogniem spalającym wszystko to, co dobre w ludzkiej duszy, a w ostateczności tak prowadzone życie duchowe kończy się złą śmiercią. Dlatego - jak przypomina mówca - należy wejść na drogę postu, aby być od tych negatywnych skutków ocalony.

\section{4. Świadomość eschatycznych skutków postu}

Istotnym zadaniem w przygotowaniu się do postu jest także wypracowanie ważnej wartości duchowej, jaką jest nadzieja. Wezwanie do jej zaakceptowania brzmi w ustach biskupa Asteriusza krótko, ale zdecydowanie: „Nie unikaj trudów wstrzemięźliwości, ale wystawiaj nadzieję do walki z obcym znojem, a lekko przebiegniesz przez czas ograniczania pokarmów" ${ }^{53}$. Mówca uważa bowiem, że nadzieja jest tą duchową mocą, która wspomoże poszczącego $\mathrm{w}$ trudach wstrzemięźliwości w taki sposób, aby ten trudny czas okazał się lekką ,walką z obcym znojem”, jak się wyraził kaznodzieja. Następnie biskup podaje okoliczności ukazujące walory nadziei: „Powtarzaj sam sobie pobożną radę: przykry jest post, ale raj przyjemny, uciążliwe pragnienie, ale blisko źródło, z którego jeśli ktoś pije, nie będzie nie wieki odczuwał pragnienia. Śmiertelne jest życie, ale blisko już zmartwychwstanie" ${ }^{54}$. Autor tej wypowiedzi poucza słuchaczy, w jaki sposób należy uformować i następnie wzmocnić nadzieję tak bardzo potrzebną do skutecznego przeżycia postu. W swym pouczeniu zastosował bowiem antytezy ,przykry post - raj przyjemny”, ,uciążliwe pragnienie - blisko źródło". Przyjemny raj i bliskie źródło odnoszą się do czasów ostatecznych, które stanowią właściwy cel życia człowieka. Te dwa odniesienia następnie w sposób jednoznaczny potwierdził wskazaniem na idee eschatologiczne, czyli na brak odczuwania pragnienia na wieki oraz nastanie zmartwychwstania po śmiertelnym życiu. Te treści z pewnością w duszach słuchaczy spotęgowały pragnienie posiadania nadziei.

\footnotetext{
52 Pseudo-Eusebius Alexandrinus, Sermo I. De ieiunio 3.

53 Asterius Amasenus, Homiliae, XIV: In principium ieiuniorum 12.

54 Asterius Amasenus, Homiliae, XIV: In principium ieiuniorum 12.
} 
Asteriusz o postrzeganiu postu w kontekście życia wiecznego wypowiedział niezwykle trafne stwierdzenie: „Post jest obrazem przyszłego życia, naśladowaniem nieśmiertelności. Tam bowiem nie ma ani napojów, ani rozkoszy podniebienia" "55. Idea postu zawarta w tych słowach jest $\mathrm{z}$ jednej strony bardzo radykalna, $\mathrm{z}$ drugiej ukazuje sens podjętego postu ujętego z perspektywy eschatologicznej. Biskup Amazji w innym miejscu swej mowy dokonał szerszego wyjaśnienia sensowności postu ze względu na przyszłe życie:

Życie wstrzemięźliwe jest obrazem przyszłego niezniszczalnego życia. Jak bowiem wtedy będziemy żyć wolni, bo zwleczemy z siebie to poddane doznaniom ciało, bez żadnej konieczności służenia żołądkowi, bez zniewolenia żadną inną namiętnością, tak samo i teraz jeśli odrzucimy wszelki przymus i pożywkę namiętności, przybliżymy się do niezniszczalności, której oczekujemy ${ }^{56}$.

Przyszłe życie Asteriusz nazywa ,życiem niezniszczalnym”, które ponadto jest wolne od doznań cielesnych, a zwłaszcza służenia żołądkowi i uległości namiętnościom. Ten obraz przyszłego życia biskup próbuje przywołać także na potrzeby doczesnych zadań w celu przybliżenia się do owej niezniszczalności. Aby zatem na ziemi uzyskać status życia wolnego, co stanie się dopiero właściwością czasów eschatycznych, mówca proponuje odrzucić wszelki przymus namiętności i też stać się wolny. Tego typu argumentacja zawierająca odniesienie do życia przyszłego mogła w opinii Asteriusza także okazać się trafnym motywem pozyskania słuchaczy do wprowadzenia wstrzemięźliwości w ich codzienność.

W podobny sposób przekonuje swoich odbiorców Pseudo-Jan Chryzostom, proponując zwrócić oczy ich wyobraźni na życie przyszłe. Bardzo wymownie brzmi jego apostrofa: „Poście, ty przez czterdzieści dni stopniowo prowadzisz nas wzwyż do nieba! Poście, ty przez usta poszczących donośnie głosisz miłosierdzie i sąd Boga" ${ }^{57}$. Według tego autora czynność poszczenia nakazuje myśleć o życiu wiecznym, czyli niebie, do którego wchodzi się poprzez miłosierdzie i sąd Boży. Na początku innej mowy Pseudo-Jan Chryzostom, jakby zapowiadając różne aspekty postu, ukazuje jego dobroczynne skutki dla duszy, stwierdzając, że ,post to wrota do raju, post to oczyszczenie $\mathrm{z}$ grzechów, post zbliża do Boga, post oczyszcza serce, post najwyższym z darów Boga, post uświęca duszę" ${ }^{98}$. Wymowa tej

\footnotetext{
55 Asterius Amasenus, Homiliae, XIV: In principium ieiuniorum 4.

56 Asterius Amasenus, Homiliae, XIV: In principium ieiuniorum 12.

57 Pseudo-Joannes Chrysostomus, De ieiunio sermones 1-7, 4.

58 Pseudo-Joannes Chrysostomus, De ieiunio sermones 1-7, 5.
} 
zachęty jest także ukierunkowana na osiągnięcie raju, co dokona się pod tym warunkiem, że najpierw chrześcijanin poprzez wprowadzenie postu w swoje życie dokona oczyszczenia duszy z grzechów, uświęcając ją.

Aleksandryjski mówca, Pseudo-Euzebiusz, również dostrzega ścisły związek postu połączonego z różnymi formami życia doskonałego a osiągnięciem chwały nieba. W swojej mowie zamieścił kilka wezwań do stałego kontrolowania codziennych zasad formacji duchowej, zwłaszcza w okresie wprowadzenia postanowienia postu. W kontekście celu ostatecznego życia ludzkiego mówca nawołuje: „Post jest bardzo cenny! Wielu dzięki postowi dostało się do nieba i współzawodniczyło z aniołami. [...] Jakże wielka jest siła postu! Przeniósł ludzi do nieba, pozwolił im zamieszkać wśród aniołów, darował radość wśród męczenników" "59. Nagrodą więc dla tych, którzy podjęli wysiłek postu, będzie przebywanie w niebie z aniołami i dzielenie z nimi oraz z męczennikami wspólnej radości. Zatem każdy poszczący w sposób indywidualny zaskarbia sobie możliwość osiągnięcia bram nieba, przy czym należy dopowiedzieć, że post z pewnością nie stanowił dla autora tych słów jedynej możliwości wejścia do nieba.

$\mathrm{Na}$ zakończenie mowy Pseudo-Euzebiusz wymienia postawy, które przygotowują chrześcijanina na osiągnięcie nieba. Należą one do podstawowych zasad codziennego postępowania chrześcijanina niezależnie od przyjęcia wymogu postu:

Bądź gościnny, dziel się swoim chlebem z biedakami, nie wynoś się z powodu dobrych uczynków, nie odłączaj się od Kościoła, nie zaniedbuj wspomnień świętych, nie pożądaj ludzkiej chwały, nie bluźnij Bogu, nie przemawiaj kwieciście, odwiedź chorego, przyjmij obcych, nie zasmucaj przyjaciół, nie rozmijaj się z prawdą, abyś doskonały pod każdym względem znalazł się ze wszystkimi świętymi w królestwie niebios, w Chrystusie Jezusie Panu naszym $^{60}$.

Dosyć zaskakująco kończy się mowa o poście, gdyż w wypowiedzianym przez Pseudo-Euzebiusza podsumowaniu całości swych pouczeń nic nie wspomniał o wymogu poszczenia i jego dobroczynnych skutkach. Tymczasem wymienił wiele pożądanych zachowań, którymi na co dzień powinien się wyróżniać chrześcijanin. Autor tych słów pragnie bez wątpienia zaznaczyć, że praktyka postu nie może stać się jedynym sposobem na osiągnięcie przeróżnych wartości duchowych, ale każdy dzień powinien być okazją do ich zdobywania, post zaś to tylko jedna $\mathrm{z}$ form wspomagających w rozwoju duchowości każdego chrześcijanina. Te wymienione

59 Pseudo-Eusebius Alexandrinus, Sermo I. De ieiunio 3.

60 Pseudo-Eusebius Alexandrinus, Sermo I. De ieiunio 8. 
przez mówcę postawy skupiają się na relacji względem bliźnich, którymi są biedacy, chorzy, obcy i przyjaciele, a także na cechach o szczególnych odniesieniach, jak m.in. Kościół, święci, Bóg czy prawda. Według mówcy zarówno jedne, jak i drugie prowadzą do doskonałości „pod każdym względem", co gwarantuje potem przebywanie w królestwie niebios. Zatem drogą prowadzącą do osiągniecia nieba są chrześcijańskie cnoty, wśród których post stanowi narzędzie ich zdobywania.

\section{Podsumowanie}

Dokonane analizy tekstów kilku mniej powszechnie znanych autorów przedstawiają dosyć szeroki wachlarz przygotowawczych propozycji w celu właściwego przeżycia postu. Słuchacze mieli możliwość wyboru zatem różnych argumentów przemawiających za podjęciem decyzji o wprowadzeniu go w osobiste życie. Niektóre wypowiedzi z omówionych tekstów wskazują także na opory w przyjęciu zalecenia Jezusa Chrystusa dotyczącego tej praktyki. Mówcy na różne sposoby starali się umotywować potrzebę postu i wszelkich jego dobroczynnych skutków dla duszy i ciała. Odnieśli swoją argumentację do religijno-antropologicznych podstaw ludzkiej egzystencji, czyli fenomenu religijności człowieka oraz jego psychofizycznej struktury. Podłoże religijności ludzkiej duszy zadecydowało u autorów analizowanych tekstów, aby wytworzyć u ich odbiorców duchowe nastawienie przed rozpoczęciem postu, które powinno charakteryzować się radosnym usposobieniem, modlitewnym skupieniem i otwartością na zdobycie pozytywnych cech w zależności od charakteru i osobowości u tego, kto zamierza wejść na drogę dosyć radykalnej wstrzemięźliwości od przyjmowania pokarmów. Integralna jedność duszy i ciała każdej jednostki ludzkiej natomiast skłoniła do opisania przez mówców przeróżnych pozytywnych skutków postu w obszarze duchowej przestrzeni oraz wprost odnoszących się do ciała. Z kolei całość wszystkich osiągnięć wynikających z podjętego trudu poszczenia składających się na duchowość chrześcijańską posiada odniesienie do przyszłego życia w królestwie niebios. $\mathrm{W}$ ten sposób zarysowana przez wymienionych autorów perspektywa zdobycia wielorakich wartości ważnych dla życia doczesnego a koniecznych dla życia wiecznego potwierdzała zasadność decyzji postu powziętej jeszcze przed rozpoczęciem właściwego okresu realizowania tej praktyki ascetycznej. 


\title{
Conditions for Good Fasting According to Selected Greek Writers of the 4th and 6th Centuries
}

\begin{abstract}
(summary)
The practice of fasting among the followers of Jesus Christ was a significant ascetic activity starting from the first generations of Christianity, because this recommendation appeared in the teaching of the Savior. That is why the shepherds of those times in various ways encouraged members of their communities to take a periodic fast, regardless of their differentiated approach to its perception. The presence of the issue of fasting in the church life of these communities is evidenced by the texts of homilies, speeches and treatises, in which there are incentives addressed to the faithful describing how to perceive the principles of fasting and its healing values. The authors who dealt with these issues were, among others, Asterius of Amazia (4th-5th century), Marcus Eremita (5th century), Pseudo-John Chrysostom (5th-6th century) and Pseudo-Eusebius of Alexandria (5th-6th century). They have left in their speeches a lot of information in the field of Christian spirituality, as well as numerous tips of practical approach regarding the introduction of fasting in everyday life. The submitted text contains a description of the initial stage, i.e. the characteristics of the conditions and requirements for undertaking fasting, which ultimately are to bring measurable benefits to the soul and body. For these reasons, the authors of these speeches wanted to shape the awareness of their recipients to a positive attitude towards fasting.
\end{abstract}

Keywords: fasting practice; speeches on fasting; Asterius of Amazia; Marcus Eremita; Pseudo-John Chrysostom; Pseudo-Eusebius of Alexandria; conditions of good fasting; early Christian spirituality

\section{Warunki dobrego postu według wybranych pisarzy greckich IV-VI wieku}

(streszczenie)

Praktykowanie postu wśród wyznawców Jezusa Chrystusa należało do istotnych czynności ascetycznych już od pierwszych pokoleń chrześcijaństwa, ponieważ to zalecenie pojawiło się w nauczaniu Zbawiciela. Dlatego pasterze tamtych czasów na różne sposoby zachęcali członków swoich wspólnot do podjęcia okresowego postu, niezależnie od ich zróżnicowanego podejścia do jego przestrzegania. O obecności zagadnienia postu w życiu kościelnym tych wspólnot świadczą teksty homilii, mów i traktatów, w których zamieszczone są zachęty kierowane do wiernych opisujące sposoby przestrzegania zasad postu oraz jego uzdrawiające wartości. Do autorów, którzy zajmowali się tymi kwestiami, należeli m.in. Asteriusz z Amazji (IV-V wiek), Marek Mnich (V wiek), Pseudo-Jan Chryzostom (V-VI wiek) oraz PseudoEuzebiusz z Aleksandrii (V-VI wiek). Pozostawili w swoich mowach wiele informacji z zakresu duchowości chrześcijańskiej, a także liczne wskazówki praktycznego podejścia dotyczące wprowadzenia postu w codzienne życie. Przedłożony tekst zawiera opis etapu wstępnego, czyli charakterystyki warunków i wymogów do podjęcia postu, które ostatecznie mają przynieść wymierne korzyści dla duszy i ciała. Z tych względów autorom owych mów zależało na ukształtowaniu świadomości swoich odbiorców do pozytywnego nastawienia wobec postu. 
Słowa kluczowe: praktyka postu; mowy o poście; Asteriusz z Amazji; Marek Mnich; Pseudo-Jan Chryzostom; Pseudo-Euzebiusz z Aleksandrii; warunki dobrego postu; duchowość wczesnochrześcijańska

\section{Bibliografia}

\section{Źródła}

Asterius Amasenus, Homiliae, XIV: In principium ieiuniorum, w: Asterius of Amasea. Homilies I-XIV, ed. C. Datema. Leiden 1970, s. 205-219, tł. M. Przyszychowska, Św. Asteriusz z Amazji, Mowa czternasta: Na poczatek świętego postu, w: Post jako praktyka duchowa. Ojcowie Kościoła o poście, red. L. Nieścior, Kraków 2019, s. 75-86.

Marcus Eremita, De ieiunio, ed. G.M. de Durand, SCh 455, Paris 2000, s. 158-166, tł. M. Warzocha - K. Żółtaszek, Marek Eremita, O poście, w: Post jako praktyka duchowa. Ojcowie Kościoła o poście, red. L. Nieścior, Kraków 2019, s. 87-90.

Pseudo-Eusebius Alexandrinus, Sermo I. De ieiunio, PG 86, 313-324, tł. M. Przyszychowska, Pseudo-Euzebiusz z Aleksandrii, Mowa pierwsza: O poście, w: Post jako praktyka duchowa. Ojcowie Kościoła o poście, red. L. Nieścior, Kraków 2019, s. 103-109.

Pseudo-Joannes Chrysostomus, De ieiunio, sermones I-VII, PG 60, 711-724, tł. M. Przyszychowska, Pseudo-Jan Chryzostom, Mowy o poście, w: Post jako praktyka duchowa. Ojcowie Kościoła o poście, red. L. Nieścior, Kraków 2019, s. 111-133.

\section{Opracowania}

Barucq A. - Grelot P., Mądrość, w: Słownik teologii biblijnej, red. X. Leon-Dufour, t1. K. Romaniuk, Poznań - Warszawa 1982, s. 459-465.

Bautz F.W., Asterius von Amaseia, w: Biographisch-Bibliographisches Kirchenlexikon, t. 1, Hamm 1975, k. 256-257.

Bralewski S., Praktykowanie postu w świetle historiografii kościelnej IV-V wieku, VoxP 59 (2013) s. 359-378.

Drączkowski F., Rewaloryzacja idei postów w nauczaniu Ojców Kościoła, w: Asceza, odczłowieczenie czy uczłowieczenie, red. W. Słomka, Lublin 1985, s. 125-136.

Espinel J.L., San Pablo y el Helenismo, „La ciencia tomista” 56 (1979) s. 503-539.

Gernet L., Anthropologie de la Grèce antique, Paris 1968.

Grimm V.E., From Feating to Fasting, the Evolution of a Sin: Attitudes to Food in Antiquity, London - New York 1996.

Harrera H.P., Legislación eclesiastica sobre el ayuno y la abstinencia: sintesis historica y comentario, Washington 1935.

Krąpiec M.A., Ja - człowiek. Zarys antropologii filozoficznej, Lublin1979.

Langerbeck H., Paulus und das Griechentum, Göttingen 1968. 
Libera P., ,, Certamen nostrum ieiunium est”. Dynamiczny wymiar postu wedtug świętego Ambrożego, VoxP 15 (1988) s. 745-758.

Małunowiczówna L., Problem przyjaźni u Bazylego, Grzegorza Teologa i Jana Chryzostoma, RH 16/3 (1968) s. 107-132.

Musurillo Th., The Problem of Ascetical Fasting in the Greek Patristic Writers, „Traditio” 12 (1956) s. 1-64.

Nieścior L., Post w czasach ojców Kościoła, w: Post jako praktyka duchowa. Ojcowie Kościoła o poście, red. L. Nieścior, Kraków 2019, s. 11-52.

Papadopoulos N., About the very early Christian Fasting, ,Deltiōn Biblikōn Meletōn” 116 (1987) s. 51-65.

Pfeil H., Das platonische Menschenbild, Aschaffenburg 1963.

Pichler Th., Das Fasten bei Basileios dem Grossen und im antiken Heidentum, Innsbruck 1955.

Pizzolato L., L'idea di amicizia antico, classico e cristiano, Torino 1993.

Prokulski W., Hellenizm św. Pawła, RBL 6 (1953) s. 25-50.

Quasten J., Patrologia, t. 2, Casale 1980.

Scarnera A., Il digiuno cristiano dalle origini al IV secolo. Contributo per una rivalutazione teologica, Roma 1990.

Stacey W.D., The Pauline View of Man, London 1956.

Voicu S.J., Asterio di Amasea, w: Dizionario patristico e di antichità cristiane, t. 1, red. A. Di Berardino, Casale Monferrato 1983, k. 420-421.

Voicu S.J., Eusebio di Alessandria (pseudo), w: Dizionario patristico e di antichità cristiane, t. 1, red. A. Di Berardino, Casale Monferrato 1983, k. 1284-1285.

Voicu S.J., Giovanni Crisostomo (pseudo), w: Dizionario patristico e di antichità cristiane, t. 2, red. A. Di Berardino, Casale Monferrato 1983, k. 1558-1559.

Voicu S.J., Une nomenclature pour les anonymes du corpus pseudo-chrysostomien, „Bysantion" 51 (1981) s. 297-305.

White C., Christian friendship in the fourth century, Cambridge 1992.

Wygralak P., Praktyka postu w klasztorach wizygockiej Hiszpanii w VI-VII wieku. Analiza regut zakonnych, w: Spiritus Sanctus et Ecclesia. Opuscula Bogdano Częsz septuagenario dedicata, red. P. Wygralak, Opuscula dedicata 10, Poznań 2015, s. 33-43.

Zdziarstek R.S., Chrystianologia św. Pawła, t. 1, Kraków 1989.

Żółtaszek K., Wstęp, w: Marek Mnich, O poście, VoxP 67 (2017) s. 813-818. 